\title{
TWO EPIGRAMS BY MELEAGER
}

Passages which have puzzled scholars are shown to be sound and indeed pointed, when the epigrams are seen in the context of their genre.

A.P. V I72 (= Gow-Page, Hell. Epigr. 4I36ff).

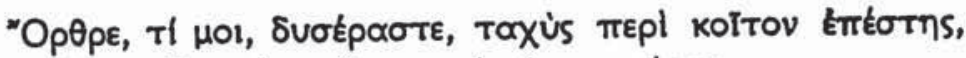

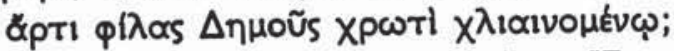

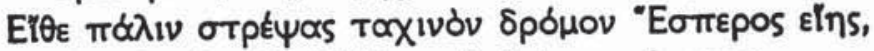

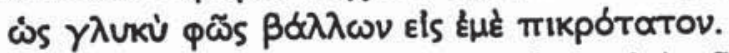

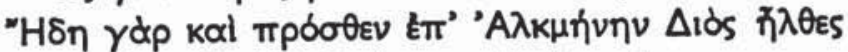

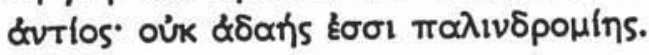

The epigram takes the form of an aubade, a genre well represented in Hellenistic poetry: cf. A.P. V 3 (= Gow-Page, Garl. Phil. Iogff, Antip. Thess.), V I73 (= Gow-Page, Hell. Epigr. 4I42ff), XII II4 (= Gow-Page, Hell. Epigr. 439off), I37 (= ibid., 4636ff) all by Meleager, V 223 (Macedonius) ${ }^{1}$. It begins with the conventional abuse of dawn or its harbingers by the lover who is unsatisfied and wishes to remain longer with the object of his passion, cf. eg. XII I37.I bpopo-

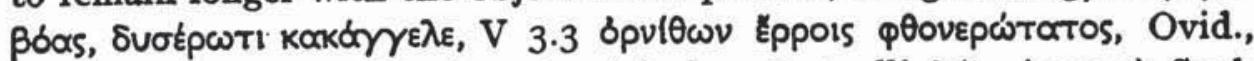
Am. I I3.9.quo properas, ingrata uiris, ingrata puellis? (to Aurora). Such an address is accompanied by a request for an extension of the night as here at line 3. Cf. Sappho I97 L.-P. (= Liban., Or. XII 99): el oũv

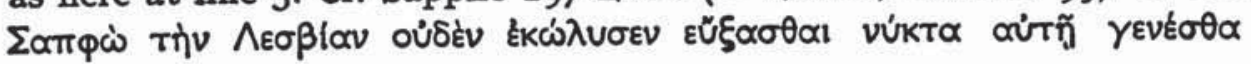

1 The genre has been traced back to Sappho: examples from Classical lite rature are listed in A. T. Hatto, Eos: an Enquiry into the Theme of Lovers' Meetings and Partings at Dawn in Poetry, London, The Hague, Paris, 1965. For Greek examples see the discussion of J. H. Mozley, p. 255ff, for Latin J. Lockwood, p. 27 Iff. 
$\delta 1 \pi \lambda \alpha \sigma i \alpha \nu \ldots{ }^{1}$. The request is sometimes justified by the case of Zeus: If. in this epigram lines 5 , a passage imitated by Ovid., loc. cit., lines 45f:

ipse deum genitor, ne te tam saepe uideret, commisit noctes in sua uota duas ?

So far Meleager is employing traditional motifs. However, at line 2 he achieves a variation in that he admits that he has not spent the

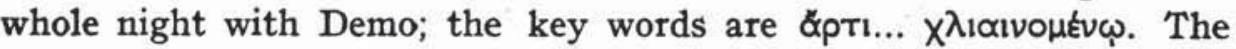
present participle $\chi^{\lambda} \lambda_{\iota} \propto\llcorner v o \mu \varepsilon v \omega$ and the word $\alpha p \tau \imath$ emphasize the fact that the poet has not been in bed long: only now is he warming himself on the girl's body. Normally the lover spends the whole night with his beloved, arriving in the evening: cf. Hesiod, Scut. Herc. 46 (of Amphitryon)

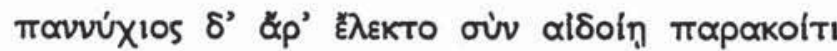

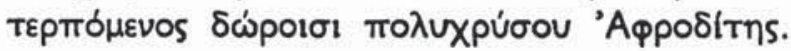

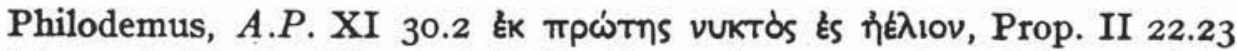
tota nocte, Paulus Silent. A.P. V $283.2 \pi d v v v x o v$, also Meleager A.P.

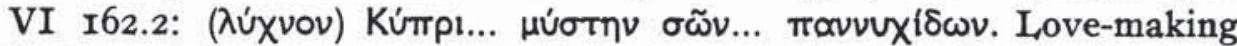
begins with the appearance of Hesperos, as in the epithalamion ${ }^{3}$; cf. line 3 and Meleager A.P. XII II4 (= Gow-Page Hell. Epigr. 439of):

'Hoũs ơ

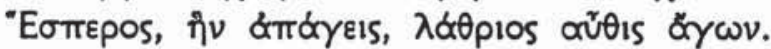

The motif is reversed by Paulus Silentiarius, loc. cit., I-4, where the girl cries because the evening star is also the morning star which will separate the lovers:

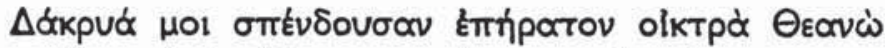

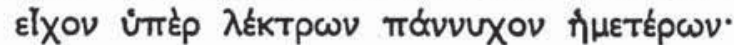

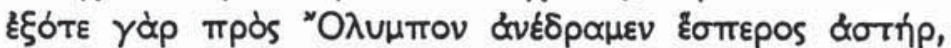

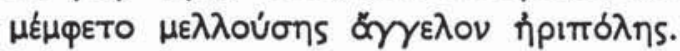

1 Mozley, art. cit., p. 260.

- Further examples are cited by Brandt, ad loc.; cf. Beckby ad A.P. V, 172.5 .

3 Cf. Viansino, Paolo Silenziario, Epigrammi, Torino, 1963, p. 139. 
Meleager has not arrived at the accustomed hour, since he is apti $\chi \chi_{i} \alpha ı v o \mu \varepsilon v \omega$, not 'eben erst erwarmt' (Beckby), but as Waltz correctly translates 'quand je commençais à me réchauffer à la chair de Demo'. The use of the present participle puzzled Graefe, who remarked ${ }^{1}$, "pro

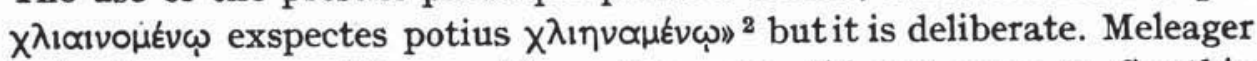
is in the same position as Propertius, who did not come to Cynthia until after the symposium, Prop. I 3.9f:

ebria cum multo traherem uestigia Baccho et quaterent sera nocte facem pueri.

That this is much later than usual is made plain by the words of Cynthia, lines $35 \mathrm{ff}$ :

tandem te nostro referens iniuria lecto alterius clausis expulit e foribus?

Namque ubi longa meae consumpsti tempora noctis languidus exactis, ei mihi, sideribus?

Meleager has varied the motif of the lover's prayer to the dawn. Usually the lover asks for a double night, twice as much time with the beloved, as in the passages quoted above (p. 83). Meleager however asks Orthros to return as Hesperos not so that he may have a double night, but in order to have a single one. His love for Demo is not particularly great; he blames the morning star although his unsatisfied desire is the result simply of his own late arrival.

At line 4 ஸे of the manuscripts was emended to $\tilde{\omega}$ by Gruter, whose emendation has been accepted by subsequent editors. However the text is sound, as I shall show. The star's light is described as $\gamma \lambda u k \dot{.} .$.

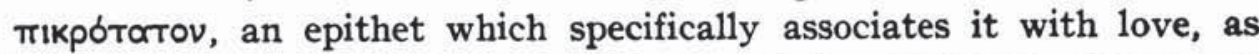
Meleager employs $\gamma \lambda$ ukúmikpos of love and its attributes, but in no

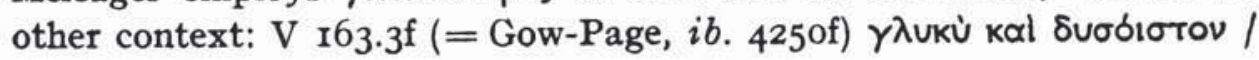

1 Meleagri Gadareni Epigrammata..., Leipzig, 181 1, p. 100.

2 For $\chi^{\lambda}$ ialve $\sigma \alpha_{1}$ of the lover at night cf. Mel. A.P. V 165.2ff (= Gow-

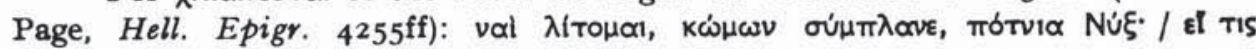

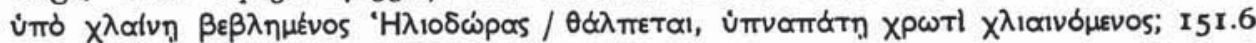

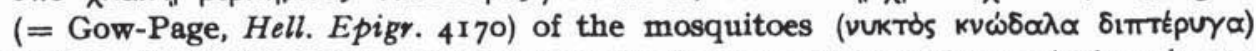

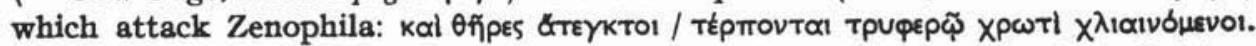
It is also used of the poet's $\psi v \times$ ' Warming itself on the image of a beautiful boy

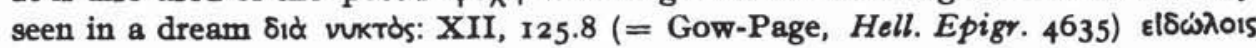

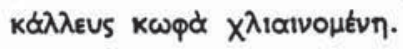




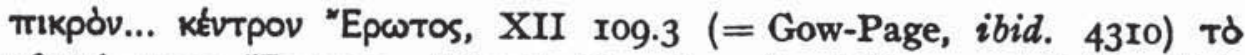

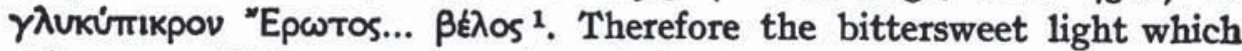
shines upon Meleager is not that of the day, but that of the only time when he can make love, namely the night. It is the light not of the morning star, but of Hesperos, and line 4 must refer to the light shed by the star when it turns into Hesperos, as the poet prays in line 3 . Cf. Meleager A.P. XII II4, Paulus Silentiarius V 283 quoted above

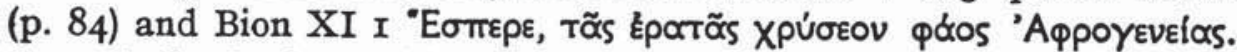

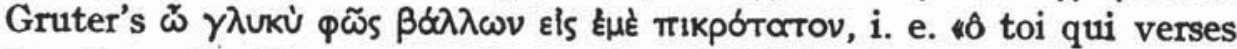
une douce lumière, pour moi si amère" (Waltz) referring to the present activity of Orthros, is not appropriate ${ }^{2}$. The reading of the manuscripts $\omega$ s is confirmed by A.P. V I73. As Waltz (ad. loc.) says, "cette pièce est la contre-partie de la précédenten. Meleager, ousted by a rival, has reversed the opening motif: he now grumbles at the morning star because it is slow to appear. Note lines 3-4:

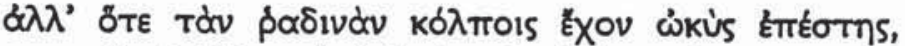

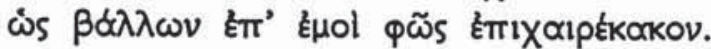

"You rose quickly, as one casting on me a light that gloated over my misfortune." This is a clear allusion to the poet's prayer at V I72.3-4: "May you turn back your swift course and be Hesperos, as one casting on me a bittersweet light), the light of evering when one can begin to make love. For $\omega s$ with present participle in the sense «als einer den,, "utpote qui» see Kühner-Gerth II, p. goff; cf. Bauer, Wörterbuch zum Neuen Testament, I97I, s. u. ம்s III I.b: "ம்s mit Ptz. gibt den Grund für eine Handlungsweise an, als einer der, deshalb weil...».

Line 5 has caused difficulty to scholars, who have been unable to

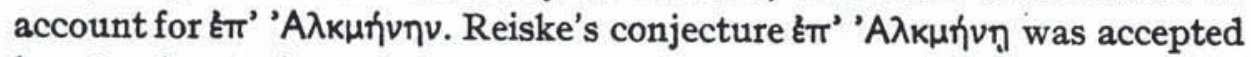
by Jacobs, Dübner, Paton and Waltz, the latter rendering it "chez

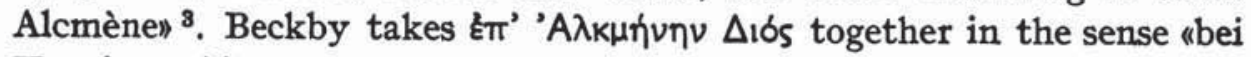
Kronions Alkmene», translating \&vilos «der eignen Laufbahn entgegen». Gow-Page, who wish to preserve the reading of the manuscripts,

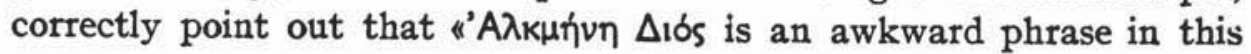

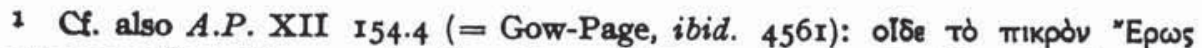

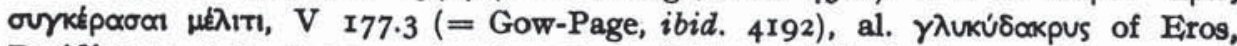

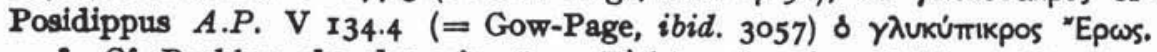

- Cf. Beckby, du, der sein süsses Licht, ach, mir so bitter entbeuts.

- See the discussion of Gow-Page ad loc. (line 4140). 
context, for its normal meaning would be 'Alcmena daughter of Zeus'n', but they are puzzled by dutios: (ibid.) "The normal sense of $i \lambda \theta \in s$ \&utios, 'you came to meet' is the reverse of what the context demands which is 'went in the opposite direction', or 'backwards'". The words $\Delta$ iós... \&utios can only mean 'face to face with Zeus', 'opposite Zeus';

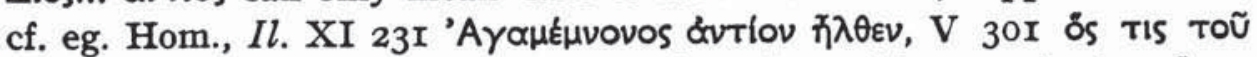

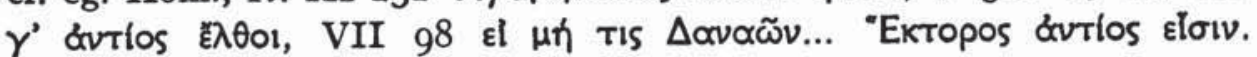
Meleager, who likes to use Homerisms ${ }^{2}$, has employed the genitive with \&vitos, which in Homer is more frequent than the dative, although

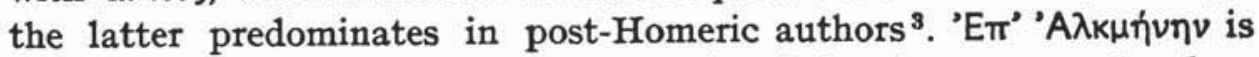
perfectly sound and is to be taken with $\left\lceil\lambda \theta_{\varepsilon s}\right.$ : 'you came head-on towards Zeus as far as Alcmena'. It is necessary to bear in mind here the ancient amatory oxrírra. Meleager imagines Zeus and Alcmena in the position favoured by the Greeks ${ }^{4}$. The star, rising from behind Alcmena, comes to overhang her ( $\boldsymbol{\varepsilon} \pi$ ' 'A (\&vTís). The word óvtios makes it clear that the star cannot have risen behind Zeus, because in that case he would not have seen it. Since it rose behind Alcmena, he saw it and immediately sent it back. We can now see that there is a parallel between lines $I$ and 5 . In the first

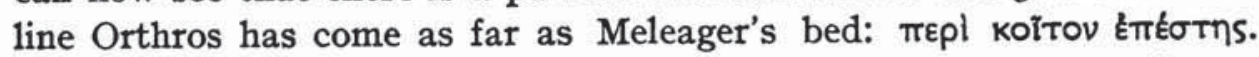
In line 5 Meleager reminds him that in the past he went as far as Alcmena. In a standard topos of prayer ${ }^{5}$, the poet asks the morning star to repeat an action performed before. On the earlier occasion the star turned back at the point where it had reached the lovers: line 6

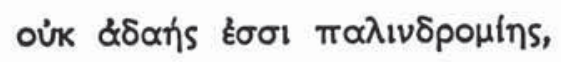

which Waltz ${ }^{6}$ correctly understood to imply, "Zeus a bien su te faire

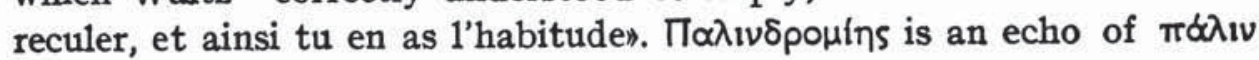

1 The passage in Herodotus, IV 205 Фepetilu in Bdrtov, which K.-G. (II. I.334 $\beta$ ) quote in support of the sense 'wife of' is dubious: see eg. Macan, How-

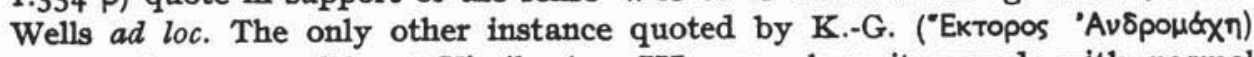
appears to occur solely at Virgil, Aen. III, 319 where it accords with normal Latin usage.

- See Radinger, Meleagros von Gadara, Innsbruck, 1895, p. $62 f$.

- LSJ s. u. dutios $\mathbf{~}$.

- Cf. Hans Licht, Sittengeschichte Griechenlands, Ergänzungsband, Zürich, 1928, pp. 4I, 53, r68-9, al. On the Romans see D. W. T. Vessey, Liverpool Class. Monthly, 1976, p. 39f. For information on this point I am indebted to Prof. G. Giangrande.

5 Cf. eg. Hom. Il. V I I5, Soph., O.T. I65 quoted by Kroll ad Catull, 34.23.

- P. 84 , n. 1 . 


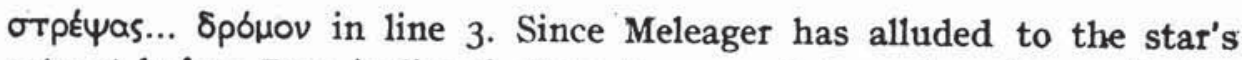
retreat before Zeus in line 6 , there is no need to seek such an allusion also in line 5 where it would be superfluous and would destroy the point of the epigram. Gow-Page want to find in line 5 the sense 'you went backwards to Zeus's Alcmena', but this is wholly inappropriate. The day-star comes to lovers, who then demand that it go back from

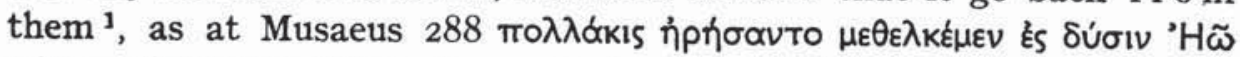
where Giangrande ${ }^{2}$ has shown that "Hero and Leandros... pray that they may be able to draw the Sun backwards, i. e. back where it is coming from».

Meleager A.P. XII r37.I-4 (= Gow-Page, Hell. Epigr. 4636-9).

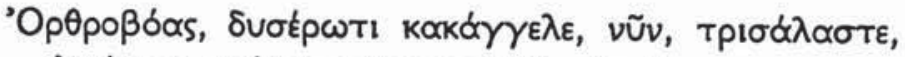

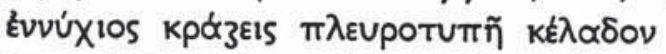

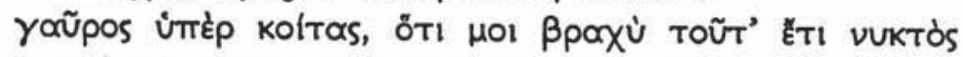

$$
\begin{aligned}
& \text { Kal Tò }
\end{aligned}
$$

The meaning of úrie koitas (line 3) has been the subject of dispute: Gow-Page (ad loc.) understand it as referring to "the poet's bed, not (as Paton takes it) the cock's". Beckby, like Paton, takes it to refer to the latter, translating "auf der Stange». However, neither of these meanings is relevant to the genre of the aubade, which Meleager is employing. koitas here has the sense 'Beischlaf' 3 as for example at

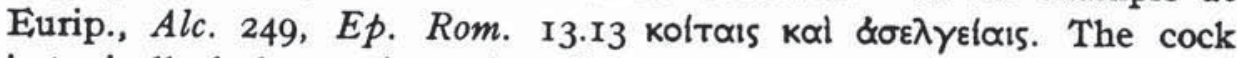
is topically lecherous in ancient literature: cf. eg. Aristotle, G.A. $749 \mathrm{~b}$

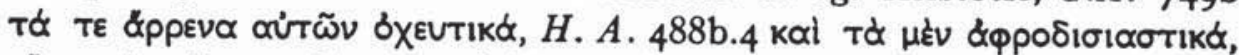

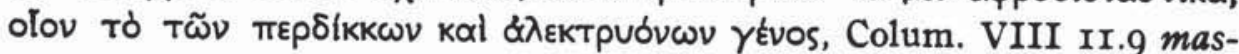
culus pauo gallinaceam salacitatem habet, atque ideo quinque feminas desiderat 4 . Cf. in Meleager A.P. VII 428.15 of a cock carved on a stele as a symbol of Antipater of Sidon: ठ́pvis $\delta^{\prime}$, ö

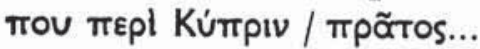

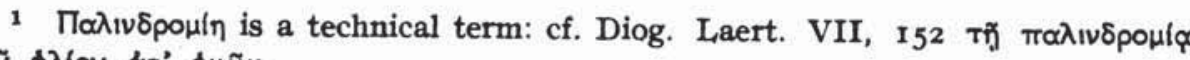

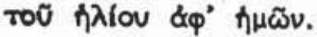

Quaderni Urbinati 9, 1970, p. 145, ibid., notes 2 and 3.

- Bauer, op. cit., s. u. kolm 2.

- D'A. W. Thompson, Glossary of Greek Birds, Hildesheim, 1966, p. 34 with

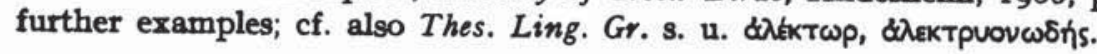


The words $\gamma \propto$ ũpos ímèp koíTas therefore mean 'arrogant about his mating'. ' $Y \pi \varepsilon \rho$ in this sense is frequent ${ }^{1}$; cf. especially its use of boast-

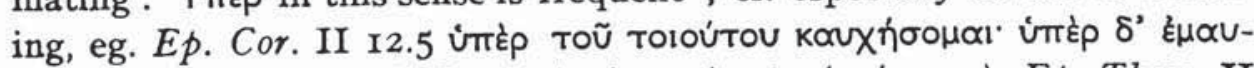

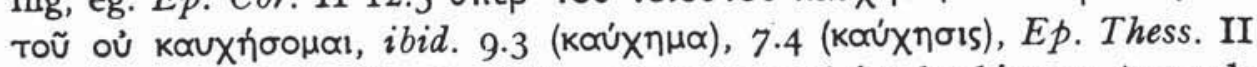

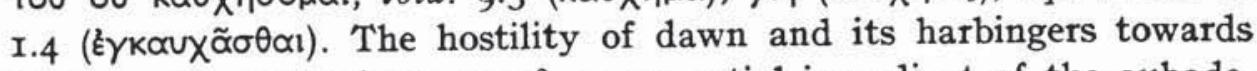
the lover is, as we have seen ${ }^{2}$, an essential ingredient of the aubade. Here the cock is schadenfroh because Meleager has so little time left for love, while for the cock mating is shortly to begin. Whereas in Greek poetry men can only make love at night ${ }^{3}$, the cock mates in the daytime.

I had already reached this conclusion when I found in Graefe * that it had been seen by Meineke. It was however rejected by Graefe (and by all subsequent editors) on the grounds that "si hoc poeta uoluisset, post koit generic reasons this is the only sense possible ${ }^{5}$. The copula $k \alpha l$ is not necessary: نंmép gives the reason for the bird's attitude.

\section{JENNIFER MOORE-BLUNT}

Portsmouth Polytechnic,

Department of Historical and Literary Studies.

1 Cf. Kühner-Gerth I, p. 487 , «dem gewöhnlicheren $\pi \varepsilon \rho l$ c. gen. sehr nahekommend;; Bauer, s. u. 1. f. mepl is a frequent variant.

P. $8 \dot{3}$.

3 See above, p. 87 .

- Op. cit., p. roof.

- For the same reason it is unnecessary to emend $\delta_{T 1}$ to $\delta_{T \varepsilon}$ as did Hermann, who is followed by Gow-Page. A further reason put forward by Graefe is that at A.P. IX 286 (Marcus Argent.). 2, kolms refers to the poet's bed. However, although Marcus Argentarius is imitating our epigram, he has achieved a variation by combining with the abuse of the bird the motif of the departure of Eros.

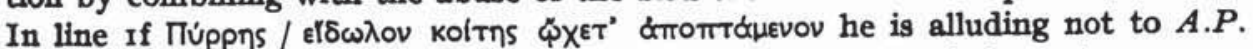

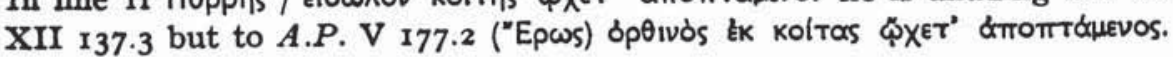

